\title{
Teacher's Mastery of English Language and Students' Academic Achievement in Higher Technical Teacher's Training College Kumba
}

\author{
Ajongakoh Raymond Bella ${ }^{1}$, Gracemary Eloheneke Moluayonge ${ }^{2}$
}

Article History:

Received 16.11.2020

Received in revised form

12.09.2021

Accepted

Available online 01.01.2022

\begin{abstract}
English is the only language of instruction recommended in all the Anglo-Saxon Universities in Cameroon as all over the world. The same reality is being followed by Francophone Universities where teachers of the opposite language must facilitate knowledge acquisition. The purpose of this study was to examine the impact of teacher's mastery of English language on students' academic achievement at HTTTC Kumba. The accessible population of the study was made up of all level 300 students and level 600 I and their teachers in all the departments of HTTTC Kumba. The participants in the study included 20 francophone teachers in the different departments, and 86 students of level 300 and 64 of level 600 I from HTTTC Kumba, through a random sampling technique. Instrument used for data collection was questionnaire which was designed for teachers and for students. The data was then exported to SPSS version 23.0 for analysis. Findings showed that: There is a significant relationship between teachers' ability to write English and students' academic achievement in HTTTC Kumba; there is a significant relationship between teachers' reading ability of the English Language and students' academic achievement in HTTTC Kumba; if there is an accurate recall of facts in English by teachers whose background is French, students will achieve higher and better. Based on these findings, it was recommended that teacher's proficiency in English should be scrutinized prior to recruitment if they are to serve in English.
\end{abstract}

(C) IJERE. All rights reserved Keywords: English reading ability, English writing ability, English concepts recall, mastery of English language, achievement

\section{Introduction}

The teaching-learning process is generally conducted in a specific language of instruction suitable to the realities of any society. The effectiveness of learning and development of skills depends also on the effectiveness of the communication processes during classroom interaction. It is therefore primordial that the teachers have a good mastery of the language of instruction so as to bring about desired learning outcomes. Language remains one of the major tools for global communication whether spoken or symbolic that enables a group of people to understand each other (Altweissi \& Maaytah, 2022; Demirbağ, 2020; Duman \& Karagöz, 2016; Eyong, Ugada \& Aminu, 2020;Gumperz, 1970; Hariyani, Ahmad, \&Marsitin, 2021; Muza, 2021; Pan et al., 2002; Scollon and Scollon, 1995). Cameroon is a bilingual country with English and French adopted as the two official languages and each used in its own right in conducting academic activities (Mackey, 1970). In the University of Buea, the language of instruction is English and as such, it expected that every teacher in the University should have a mastery of the language in order to better teach advance students' knowledge in the development of their language skills. It is the target of this study to investigate and document the actual situation on the ground.

\section{Background of the Study}

Cameroon has been rightly described by Linguists, Sociologists and Geographers, just to name a few as Africa in miniature. From the Linguistic perspective, she boasts of about286 indigenous languages spoken within the national territory (Grimes, 2000). Biloa, (2003) states that out of the four major languages of Africa, three are found in Cameroon. These are the Afro-Asiatic, Nilo-Saharan, and Niger Congo; unfortunately, none of these has been officially adopted for use in teaching and learning. With this highly diverse linguistic background, the government of Cameroon is implementing an official policy of Bilingualism. French and English are used as official tools of communication. This has its roots in the colonial period between 1919 and 1946 when Cameroon was partitioned between French and Britain following the defeat of Germany during the First World War. Since reunification in 1961, Cameroon has implemented an exoglossiclanguagepolicy based on the exclusive use of English and French as the languages of teachingand learning (Chumbow, 1990; Chiatoh, 2012). In adopting this policy, politicianspreoccupied with the desire to consolidate national unity, completely ignored theeventual consequences of such an educational option on the critical question ofeducational quality. Today, almost 60 years afterwards, these consequences are surfacingwith concerns being intensified about the falling standards of English language inparticular and the decline in academic performance across the curriculum in general. 
The policy of official bilingualism in Cameroon has had great implication on the educational policy of Cameroon. Law No 98/004 of April 1998, Part 1, Section 2 which lays guidelines for education in Cameroon, states that "The State shall institute bilingualism at all levels of education as a factor of national unity and integration". The educational system in Cameroon comprises the Anglophone subsystem and the Francophone subsystem. Both subsystems coexist but each with its specificities, for example they each differ in their assessment methods at the primary and secondary levels.

In the Anglophone schools, English is the medium of instruction while French is taught as a compulsory curricular subject. On the other hand, in the Francophone schools, French is the medium of instruction and English is a compulsory curricular subject. It is generally agreed that the input of the language teacher is an important factor for all children learning language (Anthony, 2008; Ellis \& Collins, 2009; Gass, 1997; Lightbown, 1992; Swain, 1988). Thus, as Eposi, (2009) indicates, the learners' output may be dependent, significantly, on the teacher's input. Anthony (2008), for example, argues that both the quality and the amount of language input children experience around them have an influence on both native language and second language acquisition. In other words, children who receive more input develop higher and better language skills than children who are provided with less input (Hart \& Risley, 1995). What this means is that those exposed to less input are deprived of the adequate amount and quality of language that they need to be able to give maximum output.

As Kimberly (2009) points out, for teachers to be able to administer relevant input to learners, the former must be knowledgeable in their area of study. In other words, following Metuge (2006), it is professionally necessary for a teacher to be familiar with his/her students' subject-specialism. What these authors essentially imply is that, to teach in English successfully, the teacher is expected to have a good mastery of the English language itself and be adequately knowledgeable of the salient facts that meet the needs of learners.

According to Bachman and Palmer (1996), these facts consist of knowledge of grammar which includes vocabulary, syntax and phonology; textual and pragmatic knowledge related to the communicative goals of the language user and the context in which the language is used; functional knowledge, as well as sociolinguistic knowledge. Hence, effective teaching can partly be measured by the level of a teacher's mastery of the language which could be a prime predictor of students' learning. In the light of this view, Fakeye, (2012) points out that there is a high correlation between what teachers know and what they teach, arguing that a teacher whose understanding of a given subject is thorough uses clearer language, and more connected discourse, and he/she can provide better explanations than a teacher whose background is weak.This to generally agree that the input of the language teacher is an important factor for all children learning language (Anthony, 2008; Ellis \& Collins, 2009; Gass, 1997; Lightbown, 1992; Swain, 1988). Thus, as Eposi (2009) indicates, the learners' output may be dependent, significantly, on the teacher's input.

Vygotsky's (1978) socio-constructivism theory shows that language as an essential component in achieving the goals of educational process. The use of a foreign language influence academic performance of students. Indeed, he argued that language is the main tool that promotes thinking, develops reasoning, and supports cultural activities like reading and writing. John Atkinso in self-worth simply explains that a student, despite the difficulties, encountered by the foreign language can himself challenge to succeed, (Nomlolo, 2005).

A closer look at the present situation reveals that even though concerns about quality decline are genuine, their causes have not been properly diagnosed. Arguments tendtocenter almost exclusively on peripheral areas such as linguistic interference, the training of teachers (Fontem \& Oyetade, 2005) choice of pedagogic materials and teaching methods. As yet, only very passive attention has been paid to the central question of proper choice of language of instruction which research and classroompractice have revealed to be the most fundamental factor in establishing the quality ofeducational provision. As such, half a century since the adoption of this policy, itsapplication has still not been adapted to the realities of the Cameroonian classroom. Similarly, despite more than thirty years of experimentation of mother tongue-basedbilingual education as an alternative to educational innovation (Mba\&Chiatoh, 2000), government is still lukewarm towards integrating mother tongues into theeducational system particularly at the primary level. Perhaps, it is worth noting thatmother tongue education remains an experimental program in Cameroon despite morethan 30 years of experimentation because the mother tongue is not yet part of acomprehensive language policy in which the place of indigenous languages vis-à-visEnglish and French are well-defined (Mbuagbaw, 2000).

It is further observed across the school system particularly in the English-Speaking ${ }^{2}$ subsystem that teachers whose first second language is not English but French are recruited to teach in English. It is true that this might 
have been imposed by the inadequate personnel of English extraction or simply the need to maintain some balance. Whatever the case, the consequences for effective training especially in Higher Education are pretty serious. Teachers in some classrooms in HTTTC (Higher Technical Teacher's Training College) Kumba are observed to face difficulty in expressing themselves properly in English. The result of such a situation will be ineffective learning on the part of the learners that can leads especially to a misrepresentation of concepts. Students' academic achievement in such instances as literature reports hurts greatly the development of knowledge and skills by learners.

\section{Statement of the Problem}

Students' academic achievement and their overall development of communication skills tend to suffer when teachers do not master the language of instruction. Although researchers have frequently ascribed this poor achievement and declining standards to the lack of motivation on the part of the learners (for example, Fonka, 2014), the influence of Pidgin English (PE) and French (Chumbow \& Simo-Bobda, 1995; Schroeder, 2003), and sometimes to pedagogic and socio-psychological factors such as inadequate teaching/learning resources, negative influence from the learning environment, overcrowded language classrooms, learners' attitudes towards the language, and inadequate teacher training (Fontem \& Oyetade, 2005), it would seem that there is more to the puzzle than is actually perceived, especially with respect to teaching in English by teachers whose second language is French.

Specifically, it seems that, apart from other factors, ESL teachers in Cameroon generally have a poor mastery of the language itself, a fact that can largely be blamed for the problem, if proven. It is observed that teacher's area contributing factor to the declining standards and proficiency of English in Cameroon, nothing of great substance has been done to actually investigate teachers' competence and performance in the English language to see what impact it has on the students' output. This is probably so because researchers have generally shied away from looking at the teacher in Cameroon as a potential problem. This disregard for teachers' input compounds the problem because some important aspects in the teaching/learning of English such as the irregular aspects of the language require the teachers' intuition since these can only be acquired and not learned. In other words, if teachers don't use English correctly, students will be left with no other choice than to acquire the wrong usage to which they are exposed. This backdrop has aroused the interest of the researcher to critically examine. Teacher's Mastery of English Language and the Effects on Students' Academic Achievement in HTTTC Kumba.

\section{Specific objectives:}

Specifically, the study seeks to;

1. To investigate the influence of teacher's reading and/or writing on the academic achievement of students in HTTTC Kumba;

2. To investigate the influence of teacher's inability to recall concepts on the academic achievement of students in HTTTC Kumba;

3. To investigate the influence of teacher's mastery of the language of instruction on students' attention in HTTTC Kumba

\section{Specific research questions}

1. To what extent does teacher's writingability of English affect students' academic achievement in HTTTC Kumba?

2. To what extent does teacher's reading ability of English affect students' academic achievement in HTTTC Kumba?

3. How does teacher's inability to recall concepts in English affect students' academic achievement of in HTTTC Kumba?

\section{Specific Research Hypotheses}

$\mathbf{H}_{01}$ : There is no significant relationship between teacher's ability to read English and students' academic achievement in HTTTC Kumba.

Ha1: There is a significant relationship between teacher's ability to read English and students' academic achievement in HTTTC Kumba.

$H_{02}$ : There is no significant relationship between teacher's ability to write English and students' academic achievement in HTTTC Kumba.

Ha2: There is a significant relationship between teacher's ability to write English and students' academic achievement in HTTTC Kumba. 
$\mathbf{H}_{03}$ : There is no significant relationship between teacher's inability to recall concepts in English and students' academic achievement in HTTTC Kumba.

Наз: There is no significant relationship between teacher's inability to recall concepts in English and students'

$$
\text { academic achievement in HTTC Kumba }
$$

The population of the study consisted of all the Francophone teachers and students of the first and second cycles in HTTTC Kumba. That gave a total of 1421 teachers and students. For this work, the accessible population consisted of all Level 300 students and first year level 600 students and their teachers in HTTTC Kumba. The simple random sampling technique was used to obtain a sample of 170 teachers and students as illustrated by Table 1 below.

Table 1: Distribution of Sample Population of the Study (students and teachers)

\begin{tabular}{lcccc|c}
\hline & & & \multicolumn{2}{c|}{ Students } & \\
\multirow{2}{*}{ Gender/Cycle } & Teachers & & & \multirow{2}{*}{ Total } \\
\cline { 2 - 5 } & Male & Female & Male & Female & \\
\hline First Cycle & 50 & 31 & 6 & $\mathbf{3}$ & $\mathbf{9 0}$ \\
Second Cycle & 36 & 33 & 8 & $\mathbf{3}$ & $\mathbf{8 0}$ \\
Total & $\mathbf{8 6}$ & $\mathbf{6 4}$ & $\mathbf{1 4}$ & $\mathbf{6}$ & $\mathbf{1 7 0}$ \\
\hline
\end{tabular}

Source: field survey 2021

Two questionnaires-one for the teachers and one for the students was used to collect information from the respondents. The items were developed using the Likert Scale to be responded by choosing from the options strongly agree (SA), agree (A), disagree (D) and strongly disagree (SD), depending on the specific construct under investigation. The researcher personally administered the instruments to the respondents.

\section{Results}

\begin{tabular}{|c|c|c|c|c|c|}
\hline Gender & \multicolumn{2}{|c|}{ Male } & \multicolumn{2}{|c|}{ Female } & $\begin{array}{l}\text { Tot } \\
\text { al }\end{array}$ \\
\hline Frequency (f) & \multicolumn{2}{|c|}{86} & \multicolumn{2}{|c|}{64} & 150 \\
\hline Percentage (\%) & \multicolumn{2}{|c|}{$57.33 \%$} & \multicolumn{2}{|c|}{$46.67 \%$} & 100 \\
\hline Cycle & \multicolumn{2}{|c|}{ First } & \multicolumn{2}{|c|}{ Second } & $\begin{array}{l}\text { Tot } \\
\text { al }\end{array}$ \\
\hline Frequency (f) & \multicolumn{2}{|c|}{68} & \multicolumn{2}{|c|}{82} & 150 \\
\hline Percentage $(\%)$ & \multicolumn{2}{|c|}{45.3} & \multicolumn{2}{|c|}{54.67} & 100 \\
\hline Age Range (years) & $15-19$ & $20-25$ & $26-30$ & $30^{+}$ & Total \\
\hline Frequency $(\mathrm{f})$ & 33 & 78 & 31 & 08 & 150 \\
\hline Percentage (\%) & 22.0 & 52.0 & 20.67 & 5.33 & 100 \\
\hline
\end{tabular}

\section{Analysis of Demographic Information}

The table below depicts the demographic information of the respondents.

Table 2: Gender and class enrolment of respondents

Table 2 above shows that $57.33 \%$ of the respondents selected for the study were males while $46.67 \%$ of them were female. There appears to be more males than females in each of the cycles involved in the study. Of these respondents, $45.33 \%$ of them (68) were selected from the first cycle while $54.67 \%$ of them (82) were drawn from the second cycle. Regarding the ages of the respondents, 22.00\% of them are aged between 15 and 19 while with the vast majority of them between the ages of 20 and 25 . A further $20.67 \%$ of the (31) and 5.33\% (8) are 
respectively between the ages of 26-30 and above 30.The analysis of the data obtained using the questionnaire is presented in this section according to the different specific research questions as follows:

\section{Specific Research Question One}

The first specific research question addressed the relationship between teachers' writing skills in English and how this affects students' academic achievement in HTTTC Kumba. This question was investigated using eight questionnaire items whose frequencies and mean opinions were calculated and tallied to find out whether teachers' writing of English language affects students' academic achievement. The distribution of responses pertaining to this research question is presented in Table 3 below:

Table 3:Distribution of responses on teacher's ability to write English and students' academic achievement $(\mathrm{N}=150)$

\begin{tabular}{lccccc}
\hline Cycle & $\begin{array}{c}\text { Number of } \\
\text { respondents }\end{array}$ & $\begin{array}{c}\text { Num } \\
\text { ber of } \\
\text { items }\end{array}$ & $\begin{array}{c}\text { Mean } \\
\text { Opinio } \\
\text { n }\end{array}$ & $\begin{array}{c}\text { Percenta } \\
\text { ge } \\
\text { Agree } \\
\text { (\%) }\end{array}$ & $\begin{array}{c}\text { Percentag } \\
\text { edisagree (\%) }\end{array}$ \\
\hline First Cycle & 82 & 8 & 3.01 & 77.21 & 22.79 \\
Second Cycle & 68 & 8 & 3.11 & 78.65 & 21.35 \\
All & 150 & 8 & 3.06 & 77.93 & 22.07 \\
\hline Criticalmean opinion & & & 2.50 & & \\
\hline
\end{tabular}

The results showed that more than three-quarters $(77.93 \%)$ of the respondents generally agree (mean=3.06) that teachers' ability to write English affects their academic achievement while about one-quarter $(22.07 \%)$ of them disagree. This opinion is comparatively most profound in students of the second cycle (78.65\%) and less so with students of the first cycle (77.21\%). The discrepancy in this agreement is not very high meaning that the influence is fairly similar; understandable because most teachers teach across the two cycles.

\section{Verification of Hypothesis One}

There is no significant relationship between teacher's ability to write English and students' academic achievement in HTTTC Kumba.

The independent variable in this hypothesis is teachers' ability to write English while the dependent variable is academic achievement. The scores of the independent variable were obtained from the eight questionnaire items that sought to measure writing ability while the scores of the dependent variable were obtained from the scores of the six items that were designed to measure academic achievement. The statistical analysis technique used to test this hypothesis was the Pearson Product Moment Correlation Coefficient analysis calculated using the formula below

$$
\Gamma_{\mathrm{xy}}=\frac{\sum(x-\bar{x})(y-\bar{y})}{\sqrt{\sum(x-\bar{x})^{2} \sum(y-\bar{y})^{2}}}
$$

Where $\mathrm{x}$ is the independent variable, $\mathrm{y}$ is the dependent variable and $\Gamma_{\mathrm{xy}}$ is the correlation coefficient for $x$ and $y$. The result of this analysis is presented in Table 4 below. 
Table 4: Pearson Product Moment Correlation analysis of teachers' writing ability of English and students' academic achievement in HTTTC Kumba (N=150)

\begin{tabular}{cccccc}
\hline \hline Variable & $\sum \mathrm{X}$ & $\sum \mathrm{X}^{2}$ & & \\
& $\sum \mathrm{Y}$ & $\sum \mathrm{Y}^{2}$ & & \\
& & & & & \\
& & & & & \\
\hline WritingAbility of English & 3208 & 10291246 & 28 & & \\
AcademicAchievement & 3366 & 11329956 & & \\
& & & & \\
\hline \hline
\end{tabular}

$\mathrm{p}^{*}<0.05 ; \mathrm{df}=150 ;$ critical $\Gamma_{\mathrm{xy}}=0.159$

The result of the analysis reveals that the calculated $\Gamma_{x y}$-value of 0.0 .345 is greater than the critical $\Gamma_{x y}$-value of 0.159 at.05 level of significance with 150 degrees of freedom. With the result of the analysis, the null hypothesis $\left(\mathrm{H}_{0}\right)$ was rejected and the alternative hypothesis retained. This result therefore means that there is a significant relationship between teachers' ability to write English Language and students' academic achievement in HTTTC Kumba.

Since there is a significant relationship between English writing ability and students' academic achievement, a further exploration of the result showed that the $\Gamma_{\mathrm{xy}}=0.345$ was positive and high. This indicates that the more teachers are able to correctly write the English Language, the better students will achieve.

\section{Specific Research Question Two}

The second specific research question investigated how teachers' ability to read the English Language affects students' academic achievement in HTTTC Kumba. This question was investigated using nine questionnaire items whose frequencies and mean opinions were calculated and tallied to either agree or disagree with the fact that an emotionally safe environment affects students' participation. The distribution of responses pertaining to this research question is presented in Table 5 below:

Table 5:Distribution of responses on teachers ability to read English and students' academic achievement $(\mathrm{N}=150)$

\begin{tabular}{lccccc}
\hline School Type & $\begin{array}{c}\text { Number of } \\
\text { respondents }\end{array}$ & $\begin{array}{c}\text { Num } \\
\text { ber of } \\
\text { items }\end{array}$ & $\begin{array}{l}\text { Mean } \\
\text { Opinio } \\
\text { n }\end{array}$ & $\begin{array}{l}\text { Percenta } \\
\text { ge } \\
\text { Agree } \\
\text { (\%) }\end{array}$ & $\begin{array}{c}\text { Percentag } \\
\text { edisagree (\%) }\end{array}$ \\
\hline First Cycle & 82 & 9 & 3.05 & 77.77 & 18.33 \\
Second Cycle & 68 & 9 & 3.01 & 77.91 & 18.09 \\
All & 150 & 9 & 3.03 & 77.84 & 22.16 \\
\hline Critical mean opinion & & & 2.50 & & \\
\hline
\end{tabular}

The result in table 5 shows that more than three-quarters $(77.77 \%)$ of all the respondents generally agree (mean=3.03) that their teachers' ability to read the English Language effects their academic achievement while about one quarter $(22.16 \%)$ of them disagree. This opinion is comparatively fairly similar among the students of both cycles with respectively $77.77 \%$ among first cycle students and $77.84 \%$ among second cycle students. This fairly similar opinion is testament to the fact that most of the teachers of French background teach across both cycles and $22.16 \%$ of the students face difficulties in learning because of the teachers' inability to read English.

\section{Verification of Hypothesis two}

There is no significant relationship between teacher's ability to read English and students' academic achievement in HTTTC Kumba.The independent variable in this hypothesis is teachers' reading ability of 
English while the dependent variable is students' academic achievement. The scores of the independent variable were obtained from the nine questionnaire items that sought to measure reading ability meanwhile the scores of the dependent variable were obtained from the scores of the six items that measured academic achievement. The statistical analysis technique used to test this hypothesis was the Pearson Product Moment Correlation Coefficient analysis. The result of this analysis is presented in Table 6 below.

Table 6: Pearson Product Moment Correlation analysis of teachers' reading ability of English and students' academic achievement $(\mathrm{N}=150)$

\begin{tabular}{|c|c|c|c|c|}
\hline Variable & $\begin{array}{l}\sum \mathrm{X} \\
\sum \mathrm{Y}\end{array}$ & $\begin{array}{l}\sum \mathrm{X}^{2} \\
\sum \mathrm{Y}^{2}\end{array}$ & $\sum X Y$ & $\Gamma_{x y}$ \\
\hline Reading ability of English & 3509 & \multicolumn{3}{|c|}{54} \\
\hline AcademicAchievement & 6906 & 47692836 & & \\
\hline
\end{tabular}

The result of the analysis reveals that the calculated $\Gamma_{x y}$-value of 0.482 is greater than the critical $\Gamma_{x y}$-value of 0.159 at .05 level of significance with 150 degrees of freedom. With the result of the analysis, the null hypothesis $\left(\mathrm{H}_{0}\right)$ was rejected and the alternative hypothesis retained. This result therefore means that there is a significant relationship between teachers' ability to read English and students' academic achievement in HTTTC Kumba.

A further exploration of the result shows that $\Gamma_{x y}$ calculated was high and positive. This means that if teachers improve the reading ability of English, their students will also achieve higher.

\section{Specific Research Question three}

The second specific research question investigated the extent to which teachers' inability to recall concepts when teaching affect students' academic achievement in HTTTC Kumba. This question was investigated using ten questionnaire items whose frequencies and mean opinions were calculated and tallied to find out the extent to students' to recall concepts affect students' academic achievement. The distribution of responses pertaining to this research question is presented in Table 7 below:

Table 7: Distribution of responses on teachers' ability to recall concepts and students' academic achievement $(\mathrm{N}=150)$

\begin{tabular}{lccccc}
\hline School Type & $\begin{array}{c}\text { Number of } \\
\text { respondents }\end{array}$ & $\begin{array}{c}\text { Number } \\
\text { of items }\end{array}$ & $\begin{array}{c}\text { Mean } \\
\text { Opinion }\end{array}$ & $\begin{array}{c}\text { Percentage } \\
\text { Agree (\%) }\end{array}$ & $\begin{array}{c}\text { Percentage } \\
\text { disagree (\%) }\end{array}$ \\
\hline First Cycle & 82 & 10 & 2.93 & 69.51 & 30.49 \\
Second Cycle & 68 & 10 & 2.63 & 55.07 & 44.93 \\
All & 150 & 10 & 2.73 & 62.29 & 37.71 \\
\hline Critical mean opinion & & 2.50 & \\
\hline
\end{tabular}

The result in table 10 shows that $62.29 \%$ of all the respondents generally agree (mean=2.73) that teachers' inability to recall concepts affect their academic achievement while $37.71 \%$ of them disagree. This opinion is comparatively most profound among students of the first cycle (69.51\%) and less so among students of the second cycle (55.07\%). This result actually means that $62.29 \%$ of the respondents are of the opinion that their teachers of French background do not forget concepts while teaching while more than $30 \%$ of them tend to forget. 
There is no significant relationship between teachers' inability to recall concepts and students' academic achievement in HTTTC Kumba.

The independent variable in this hypothesis is teachers' inability to recall concepts while the dependent variable is students' academic achievement. The scores of the independent variable were obtained from the ten questionnaire items that sought to measure the recall of concepts meanwhile the scores of the dependent variable were obtained from the six questionnaire items that measured academic achievement. The statistical analysis technique used to test this hypothesis was the Pearson Product Moment Correlation Coefficient analysis. The result of this analysis is presented in Table 8 below.

Table 8: Pearson Product Moment Correlation analysis of teachers' inability to recall concepts and students' academic achievement $(\mathrm{N}=150)$

\begin{tabular}{|c|c|c|c|c|}
\hline Variable & $\begin{array}{l}\sum \mathrm{X} \\
\sum \mathrm{Y}\end{array}$ & $\begin{array}{l}\sum \mathrm{X}^{2} \\
\sum \mathrm{Y}^{2}\end{array}$ & $\sum X Y$ & $\Gamma_{x y}$ \\
\hline Inability to Recall Concepts & \multicolumn{4}{|c|}{66} \\
\hline AcademicAchievement & 6906 & 47692836 & & \\
\hline
\end{tabular}

The result of the analysis reveals that the calculated $\Gamma_{x y}$-value of 0.430 is greater than the critical $\Gamma_{x y}-$ value of 0.159 at.05 level of significance with 150 degrees of freedom. With the result of the analysis, the null hypothesis $\left(\mathrm{H}_{0}\right)$ was rejected and the alternative hypothesis retained. This result therefore means that there is a significant relationship between teachers' inability to recall concepts and students' academic achievement in HTTTC Kumba. This relationship is significant at 0.05 level of significance across all cycles. It therefore means that the more teachers are able to accurately recall concepts, the more their students will achieve.

\section{Analysis of Data from the Questionnaire for Teachers}

Similarly, questions regarding teacher's mastery of the English Language as the language of instruction were posed to teachers directly pertaining to writing, reading and recalling. Their opinions are summarized as follows:

\section{Teacher Reading Skills}

This was investigated by putting eight questionnaire items to the teachers of French Speaking background in HTTTC Kumba. The distribution of teachers' responses about their reading skills is presented in Table 9.

Table 9:Distribution of responses on teachers reading skills of English $(\mathrm{N}=20)$

\begin{tabular}{|c|c|c|c|c|c|c|}
\hline \multirow[t]{2}{*}{ Statements } & \multirow[b]{2}{*}{$\begin{array}{l}\text { Strongly } \\
\text { Agree SA }\end{array}$} & \multicolumn{3}{|c|}{ Stretched } & \multicolumn{2}{|c|}{ Collapsed } \\
\hline & & $\begin{array}{l}\text { Agree } \\
\text { A }\end{array}$ & $\begin{array}{l}\text { Disagre } \\
\mathrm{e}_{\mathrm{D}}\end{array}$ & $\begin{array}{l}\text { Strongly } \\
\text { Disagree SD }\end{array}$ & SA/A & D/SD \\
\hline $\begin{array}{l}\text { Learning how to read in English is } \\
\text { important for me to succeed in my } \\
\text { teaching }\end{array}$ & $\begin{array}{c}15 \\
(75.0 \%)\end{array}$ & $\begin{array}{c}5 \\
(25.0 \%)\end{array}$ & $\begin{array}{c}00 \\
(00 \%)\end{array}$ & $\begin{array}{c}00 \\
(00 \%)\end{array}$ & $\begin{array}{c}20 \\
(100.0 \%)\end{array}$ & $\begin{array}{c}00 \\
(00 \%)\end{array}$ \\
\hline $\begin{array}{l}\text { Reading ability is helping me to } \\
\text { achieve the educational goal }\end{array}$ & $\begin{array}{c}11 \\
(55.0 \%)\end{array}$ & $\begin{array}{c}9 \\
(45.0 \%)\end{array}$ & $\begin{array}{c}00 \\
(00 \%)\end{array}$ & $\begin{array}{c}00 \\
(00 \%)\end{array}$ & $\begin{array}{c}20 \\
(100 \%)\end{array}$ & $\begin{array}{c}00 \\
(00 \%)\end{array}$ \\
\hline $\begin{array}{l}\text { Reading ability in English helps } \\
\text { me to study review my notes }\end{array}$ & $\begin{array}{c}9 \\
(45.0 \%) \\
\end{array}$ & $\begin{array}{c}10 \\
(50.0 \%) \\
\end{array}$ & $\begin{array}{c}1 \\
(5.0 \%) \\
\end{array}$ & $\begin{array}{c}00 \\
(00 \%) \\
\end{array}$ & $\begin{array}{c}19 \\
(95.0 \%) \\
\end{array}$ & $\begin{array}{c}1 \\
(5.0 \%) \\
\end{array}$ \\
\hline $\begin{array}{l}\text { Reading is help me to construct } \\
\text { the exam questions. }\end{array}$ & $\begin{array}{c}11 \\
(55.0 \%)\end{array}$ & $\begin{array}{c}7 \\
(35.0 \%) \\
\end{array}$ & $\begin{array}{c}2 \\
(10.0 \%)\end{array}$ & $\begin{array}{c}00 \\
(00 \%)\end{array}$ & $\begin{array}{c}18 \\
(90.0 \%)\end{array}$ & $\begin{array}{c}2 \\
(10.0 \%) \\
\end{array}$ \\
\hline $\begin{array}{l}\text { Reading helps me to correct } \\
\text { students scripts }\end{array}$ & $\begin{array}{c}12 \\
(60.0 \%)\end{array}$ & $\begin{array}{c}6 \\
(30.0 \%)\end{array}$ & $\begin{array}{c}2 \\
(10.0 \%)\end{array}$ & $\begin{array}{c}00 \\
(00 \%)\end{array}$ & $\begin{array}{c}18 \\
(90.0 \%)\end{array}$ & $\begin{array}{c}2 \\
(10.0 \%)\end{array}$ \\
\hline $\begin{array}{c}\text { Reading ability helps me to } \\
\text { discuss learning with others teachers }\end{array}$ & $\begin{array}{c}8 \\
(40.0 \%)\end{array}$ & $\begin{array}{c}12 \\
(60.0 \%)\end{array}$ & $\begin{array}{c}00 \\
(00 \%)\end{array}$ & $\begin{array}{c}00 \\
(00 \%)\end{array}$ & $\begin{array}{c}20 \\
(100 \%)\end{array}$ & $\begin{array}{c}00 \\
(00 \%)\end{array}$ \\
\hline $\begin{array}{l}\text { Reading ability help me to learn } \\
\text { from my mistakes }\end{array}$ & $\begin{array}{c}13 \\
(65.0 \%) \\
\end{array}$ & $\begin{array}{c}7 \\
(35.0 \%) \\
\end{array}$ & $\begin{array}{c}00 \\
(00 \%) \\
\end{array}$ & $\begin{array}{c}00 \\
(00 \%) \\
\end{array}$ & $\begin{array}{c}20 \\
(100.0 \%) \\
\end{array}$ & $\begin{array}{c}00 \\
(00 \%)\end{array}$ \\
\hline $\begin{array}{llll}\text { I face difficulties reading in } \\
\text { English }\end{array}$ & $\begin{array}{c}2 \\
(10.0 \%)\end{array}$ & $\begin{array}{c}3 \\
(15.0 \%) \\
\end{array}$ & $\begin{array}{c}15 \\
(75.0 \%)\end{array}$ & $\begin{array}{c}00 \\
(00 \%)\end{array}$ & $\begin{array}{c}5 \\
(25.0 \%)\end{array}$ & $\begin{array}{c}15 \\
(75.0 \%)\end{array}$ \\
\hline Multiple response set & $\begin{array}{c}81 \\
(50.6 \%)\end{array}$ & $\begin{array}{c}59 \\
(36.9 \%)\end{array}$ & $\begin{array}{c}20 \\
(12.5 \%)\end{array}$ & $\begin{array}{c}\mathbf{0 0} \\
(00 \%)\end{array}$ & $\begin{array}{c}\mathbf{1 4 0} \\
(87.5 \%)\end{array}$ & $\begin{array}{c}20 \\
(12.5 \%)\end{array}$ \\
\hline
\end{tabular}


The result in table 9 reveals that $87.5 \%$ of the respondents generally agree that they have no problems with the reading of English Language, while $12.5 \%$ of them indicate that they have difficulties with the English Language. This is not as high as the students opinions depicted.

\section{Teacher Speaking Abilities}

This was investigated by putting seven questionnaire items to the teachers of French Speaking background in HTTTC Kumba. The distribution of teachers' responses about their speaking skills is presented in Table 10 below:

Table 10:Distribution of responses on teachers English speaking skills $(\mathrm{N}=20)$

Statements

Stretched

Collapsed

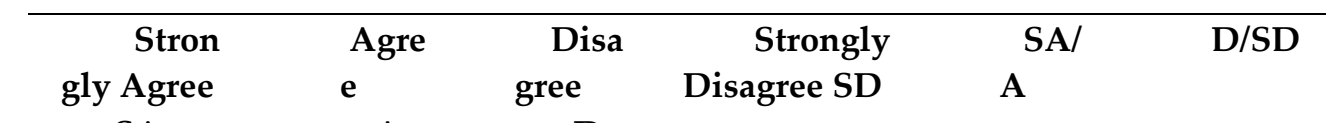

SA

Speaking English is

important to me as a

teacher

$\begin{array}{lll}14 & \text { A } & 00\end{array}$

00

$(30.0 \quad(00 \%$

) $\%)$

Speaking ability

helps in exchange $(65.0 \%$

$\%)$

especially classroom

$13 \quad 7 \quad 00$

00

(35.0

$(00 \%$

$\%)$

)

A

interaction

\begin{tabular}{|c|c|c|c|c|c|c|}
\hline $\begin{array}{l}\text { Speaking ability } \\
\text { helps to participate in the } \\
\text { development of } \\
\text { educational workforce }\end{array}$ & $\begin{array}{l}12 \\
(60.0 \% \\
)\end{array}$ & $\begin{array}{c}7 \\
(35.0 \\
\%)\end{array}$ & $\begin{array}{c}1 \\
(5.0 \\
\%)\end{array}$ & $\begin{array}{c}00 \\
(00 \%)\end{array}$ & $\begin{array}{l}19 \\
(95.0 \\
\%)\end{array}$ & $\begin{array}{c}1 \\
(5.0 \%)\end{array}$ \\
\hline $\begin{array}{l}\text { Speaking ability } \\
\text { helps in critical thinking }\end{array}$ & $\begin{array}{l}10 \\
(50.0 \% \\
\end{array}$ & $\begin{array}{c}4 \\
(20.0 \\
\%)\end{array}$ & $\begin{array}{c}4 \\
(20.0 \\
\%) \\
\end{array}$ & $\begin{array}{c}2 \\
(10.0 \%)\end{array}$ & $\begin{array}{r}14 \\
(70 . \\
0 \%) \\
\end{array}$ & $\begin{array}{c}6 \\
(30.0 \% \\
\end{array}$ \\
\hline $\begin{array}{l}\text { Speaking ability } \\
\text { helps me to contribute to } \\
\text { students' success }\end{array}$ & $\begin{array}{c}11 \\
(55.0 \% \\
\end{array}$ & $\begin{array}{c}7 \\
(35.0 \\
\%) \\
\end{array}$ & $\begin{array}{c}2 \\
(10.0 \\
\%) \\
\end{array}$ & $\begin{array}{c}00 \\
(00 \%)\end{array}$ & $\begin{array}{r}18 \\
(90 . \\
0 \%) \\
\end{array}$ & $\begin{array}{c}2 \\
(10.0 \%)\end{array}$ \\
\hline $\begin{array}{l}\text { I practice English by } \\
\text { speaking with students }\end{array}$ & $\begin{array}{l}5 \\
(25.0 \% \\
\end{array}$ & $\begin{array}{c}9 \\
(45.0 \\
\%) \\
\end{array}$ & $\begin{array}{c}5 \\
(25.0 \\
\%) \\
\end{array}$ & $\begin{array}{c}1 \\
(5.0 \%)\end{array}$ & $\begin{array}{r}14 \\
(70 . \\
0 \%) \\
\end{array}$ & $\begin{array}{c}6 \\
(30.0 \%)\end{array}$ \\
\hline $\begin{array}{l}\quad \text { I make lists of } \\
\text { expressions, words to } \\
\text { learn. }\end{array}$ & $\begin{array}{c}1 \\
(5.0 \%)\end{array}$ & $\begin{array}{l}10 \\
(10.0 \\
\%)\end{array}$ & $\begin{array}{c}8 \\
(40.0 \\
\%) \\
\end{array}$ & $\begin{array}{c}1 \\
(5.0 \%)\end{array}$ & $\begin{array}{l}11 \\
(55.0 \\
\%) \\
\end{array}$ & $\begin{array}{c}9 \\
(45.0 \%)\end{array}$ \\
\hline $\begin{array}{l}\text { Multiple } \\
\text { response set }\end{array}$ & $\begin{array}{c}66 \\
(47.1 \% \\
)\end{array}$ & $\begin{array}{c}50 \\
(35.7 \\
\%)\end{array}$ & $\begin{array}{l}20 \\
(14.3 \\
\%)\end{array}$ & $\begin{array}{c}4 \\
(2.9 \%)\end{array}$ & $\begin{array}{l}116 \\
(82 . \\
9 \%)\end{array}$ & $\begin{array}{c}24 \\
(17.1 \%)\end{array}$ \\
\hline
\end{tabular}

The result in table 10 reveals that $82.9 \%$ of the respondents generally agree that their ability to teach in class is influenced by their speaking of the English language while $17.1 \%$ of them agree. The ability to speak the language according to the teachers clearly influences the way learners master whatever is being taught.

\section{Teacher Ability to Recall Concepts}

This was investigated by putting seven questionnaire items to the teachers of French Speaking background in HTTTC Kumba on how easy it is for them to recall concepts in English. The distribution of teachers' responses about their recall ability is presented in Table 11 below. 
Table 11:Distribution of responses on teachers ability to recall concepts $(\mathrm{N}=20)$

\begin{tabular}{|c|c|c|c|c|c|c|}
\hline \multirow[t]{2}{*}{ Statements } & \multicolumn{5}{|c|}{ Stretched } & \multirow{2}{*}{$\begin{array}{r}\text { Collapsed } \\
\text { D/SD }\end{array}$} \\
\hline & $\begin{array}{l}\text { Strongly } \\
\text { Agree SA }\end{array}$ & $\begin{array}{c}\text { Agree } \\
\text { A }\end{array}$ & $\begin{array}{c}\text { Disagree } \\
\text { D }\end{array}$ & $\begin{array}{r}\text { Strongly } \\
\text { Disagree SD }\end{array}$ & SA/A & \\
\hline $\begin{array}{l}\quad \text { I find difficulties } \\
\text { recalling concepts on } \\
\text { English }\end{array}$ & $\begin{array}{c}2 \\
(10.0 \% \\
)^{2}\end{array}$ & $\begin{array}{l}8 \\
(40.0 \\
\%)^{-}\end{array}$ & )$^{4}$ & $\begin{array}{c}6 \\
(30.0 \%)\end{array}$ & $\begin{array}{l}10 \\
(50.0 \% \\
\end{array}$ & $\begin{array}{l}10 \\
(50.0 \% \\
\end{array}$ \\
\hline $\begin{array}{l}\text { Recalling concepts } \\
\text { helps me to follow up } \\
\text { student learning }\end{array}$ & $\begin{array}{c}7 \\
(35.0 \% \\
\end{array}$ & $\begin{array}{l}10 \\
(50.0 \\
\%)\end{array}$ & $\begin{array}{c}1 \\
\%)^{(5.0} \\
\end{array}$ & $\begin{array}{c}2 \\
(10.0 \%)\end{array}$ & $\begin{array}{r}17 \\
(85 . \\
0 \%)\end{array}$ & $\begin{array}{c}3 \\
(15.0 \% \\
\end{array}$ \\
\hline $\begin{array}{l}\text { Recalling concepts } \\
\text { ability helps me the } \\
\text { explain during classroom }\end{array}$ & $\begin{array}{c}5 \\
(25.0 \% \\
\end{array}$ & $\begin{array}{l}13 \\
(65.0 \\
\%) \\
\end{array}$ & $\begin{array}{c}2 \\
(10.0 \\
\%)\end{array}$ & $\begin{array}{c}00 \\
(00 \%)\end{array}$ & $\begin{array}{l}18 \\
(90.0 \\
\%) \\
\end{array}$ & $\begin{array}{c}2 \\
(10.0 \% \\
\end{array}$ \\
\hline $\begin{array}{l}\text { Recalling concept } \\
\text { ability permits me to } \\
\text { understand easily how to } \\
\text { plan assessments }\end{array}$ & $\begin{array}{l}5 \\
(25.0 \% \\
\end{array}$ & $\begin{array}{l}12 \\
(60.0 \\
\%)\end{array}$ & $\begin{array}{l}3 \\
(15.0 \\
\%)\end{array}$ & $\begin{array}{c}00 \\
(00 \%)\end{array}$ & $\begin{array}{l}17 \\
(85 . \\
0 \%)\end{array}$ & $\begin{array}{c}3 \\
(15.0 \% \\
()\end{array}$ \\
\hline $\begin{array}{l}\text { Recalling concept } \\
\text { ability helps me to think } \\
\text { about what to learn to } \\
\text { improve my speaking in } \\
\text { the classroom. }\end{array}$ & $\begin{array}{c}6 \\
(30.0 \% \\
()\end{array}$ & $\begin{array}{l}12 \\
(60.0 \\
\%)\end{array}$ & $\begin{array}{c}2 \\
(10.0 \\
\%)\end{array}$ & $\begin{array}{c}00 \\
(00 \%)\end{array}$ & $\begin{array}{r}18 \\
(90 . \\
0 \%)\end{array}$ & $\begin{array}{c}2 \\
(10.0 \%)\end{array}$ \\
\hline $\begin{array}{l}\text { While I recall } \\
\text { concepts, I correct myself } \\
\text { when I notice that I made } \\
\text { a mistake. }\end{array}$ & $\begin{array}{c}3 \\
(15.0 \%)\end{array}$ & $\begin{array}{c}15 \\
(75.0 \%)\end{array}$ & $\begin{array}{c}2 \\
(10.0 \%)\end{array}$ & $\begin{array}{c}00 \\
(00 \%)\end{array}$ & $\begin{array}{c}18 \\
(70.0 \%)\end{array}$ & $\begin{array}{c}2 \\
(10.0 \%)\end{array}$ \\
\hline $\begin{array}{l}\text { I can easily recall } \\
\text { concepts in French and } \\
\text { note in English }\end{array}$ & $\begin{array}{r}3 \\
(15.0 \%)\end{array}$ & $\begin{array}{r}7 \\
(35.0 \%)\end{array}$ & $\begin{array}{c}7 \\
(35.0 \%)\end{array}$ & $\begin{array}{c}3 \\
(15.0 \%)\end{array}$ & $\begin{array}{c}10 \\
(50.0 \%)\end{array}$ & $\begin{array}{c}10 \\
(50.0 \%)\end{array}$ \\
\hline $\begin{array}{l}\text { Multiple } \\
\text { response set }\end{array}$ & $(19.4 \%)^{31}$ & $\begin{array}{r}77 \\
(48.1 \%)^{7}\end{array}$ & $\begin{array}{r}21 \\
(13.1 \%)\end{array}$ & $\begin{array}{c}11 \\
(6.9 \%)\end{array}$ & $\begin{array}{l}108 \\
(67.5 \%)\end{array}$ & $\begin{array}{c}42 \\
(32.5 \%)\end{array}$ \\
\hline
\end{tabular}

The result in table 11 reveals that about two-thirds (67.5\%) of the respondents generally agree that they do not have problems recalling concepts while teaching in the English language while about one-third (32.5\%) of them disagree. The ability to recall concepts in the language of instruction according to the teachers clearly influences the way learners master whatever is being taught.

\section{Discussion}

There is enough evidence to support the fact that teachers' mastery of the English Language and students' academic achievement in HTTTC Kumba. These findings were in concordance with some past writings and findings of other authors, as demonstrated below. Discussion of the findings is presented in the following paragraphs based on the summaries of findings got from tests of hypotheses.

1. There is a significant relationship between teachers' ability to write English and students' academic achievement in HTTTC Kumba.

This finding is in accord with Baptist (2004) who conducted a study on students' participation and performance in 'fasihi' and literature in teachers training colleges with the focus on whether there was progress or regression using the LOI in these two subjects. He explained in his findings that $62 \%$ of tutors in teacher training colleges said the relation between language and performance is crucial towards enabling students perform well in their academic subjects. Baptist continues to elaborate that English which is the language of instruction in secondary schools is a problem in which most students are incompetent or have low 
proficiency in the language since it's mainly a classroom language used only in class and not outside; students are unable to fully benefit their education due to pedagogical hindrances where students understand very little and thus perform poorly in examinations.

Again, Prophet and Badede (2006) in their study on the effects of changing the language used in the science examinations in junior secondary schools. The study shows that language can be a barrier to understanding examination questions particularly the wording of the questions in science examinations. Students studying in rural schools seem to be more affected since their language skills in English are limited due to lack of opportunity to develop them unlike those in urban schools.

2. There is a significant relationship between teachers' reading ability of the English Language and students' academic achievement in HTTTC Kumba.

This finding falls in line with Howie (2003) who conducted a study pertaining to how language and other background factors affect the performance of students in mathematics in South African secondary schools. The research confirmed that proficiency in English language does correlate with their achievement in mathematics; students with high scores in mathematics also performed well in the English test administered while those with low scores didn't. Findings of the study also show that students who came from homes where either English or Afrikaans was used achieved better scores in both Mathematics and English tests unlike those who did not. The low English language proficiency is also closely linked to students' lack of books to use at home (Howie, 2002). Also the average English test score was very low and the overall English skills were poor. Other influences include location of the school in rural or urban areas, teachers' attitudes and belief and commitment also contributes to mathematics achievement as well as students' socioeconomic status to a certain extent. English language has a strong effect on the achievement of mathematics; therefore, it needs to be given more attention as a subject and as a medium of instruction.

Mole (2006) investigated the factors affecting the learning of English as a second language macro skill among Tongan secondary students. This study aimed at determining factors which might have impact on the learning of English as a second language macro skill (reading, writing, listening, and speaking) by Tongan secondary learners. Seven factors were shown to have significant correlations with the students' learning of English macro skills at secondary school. They were: the age of the students; their perceived ability in English; frequency of use of English with non-Tongan speakers; use of English to read for enjoyment; use of English for communication at home; integrative motivation; and career aspirations. The multiple regressions showed that $40 \%$ to $50 \%$ of the variances in reading, writing and listening could be accounted for by the same seven factors.

Furthermore, Hand, Hohenshell \&Vaughan (2007), examined the effect of multiple writing tasks on year 10 biology students' understanding of cell and molecular biology concepts. This reports on a study that examined the cumulative effects on students' learning of science, and perceptions of the role of writing in learning, when the students engaged in multiple writing tasks with planning strategy support. Results from the quantitative component indicated that multiple, non-conventional writing had a significant benefit in helping students learn Molecular Biology. The results for the Cell unit were not so conclusive suggesting the strategies are most useful for novel content. The interviews with students demonstrated that they understood and engaged successfully with both the conceptual and linguistic demands of the tasks. These findings, taken as a whole, confirm that multiple writing tasks can support effective student learning provided various pedagogical conditions are met.

3. If there is an accurate recall of fact in English by teachers who background is French, students will achieve higher and better.

The result of the finding is in agreement with Neema (2010) who conducted a study on "The Influence of the Language of Instruction on Students' Academic Performance in Secondary Schools". Two subjects, that is, History and English were used to examine the differences and similarities in students' performances. The findings indicate that students in urban secondary school performed better than students at the rural school. The mock examination performance results for History and English verified this; however, the difference between the schools is marginal. This study considers the fact that English is still the language of instruction; 
therefore, measured need to be taken to solve the language problem. In order to work on this language problem, the teaching of English as a subject should be enhanced to promote effective and efficient teaching and learning in classrooms. Reading programs and oral exercises for students should be initiated in schools to develop students"e language skills. English training workshops and professional pedagogy workshops for all subject teachers should be organized to improve teachers' language and pedagogy skills.

Also, Aina(2014), conducted a study on "The influence of English language on students' academic performance in physics in college of education". Results indicated that English language influences students' academic performance in physics and there was significant difference in students' performance based on gender in physics while there was no significant difference in English language based on gender.

The findings as presented shows that there are similarities in the result and findings of other researchers who investigated the relevance of the language of instruction in the teaching/ learning process. Despite the fact that the samples used a different across different countries shows that the relationship is significant.

\section{Conclusion and Recommendation}

The language of instruction is the only possible way of causing the students to learn effectively. The teacher must have a mastery of it if their teaching is to be meaningful. It should be recalled that this study targeted teachers of French background in HTTTC Kumba. At the end of the study, it was concluded that these teachers face some difficulties in reading, writing and recalling of concepts in English. Students as a result agree that for this reason, some of them face difficulties following up and understanding what some of the teachers are teaching.

Based on the findings, analysis and conclusions of the study, the following recommendations have been made:

1. Teacher's proficiency in English should be scrutinized prior to recruitment if they are to serve in English.

2. Teachers should be encouraged to further their knowledge and perfect their language skills.

3. Refresher courses could also be organized in regional Linguistic Centres for these teachers to polish their Language.

\section{Suggestions for Further Research}

This study was limited to the mastery of Language of instruction and academic achievement in HTTTC Kumba. The design used was the descriptive survey and the instrument for data collection was questionnaire. Some suggestions for future research in the area of special education needs could be made based on the following:

1. The same study could be extended to cover all higher institutions of learning in Cameroon.

2. A study could be carried out to evaluate the extent of proficiency of the teachers in relation to academic achievement.

3. The extent to which students develop language skills by modeling their teachers.

\section{Limitations of the Study}

- Only one instrument (questionnaire) was used for this study which might not have elicited all necessary information for analysis as could be possible.

- The information provided by the respondents could not be objectively verified as true.

- In addition to the current socio-political crisis in the North West and South West Regions coupled with the outbreak of the Corona Virus pandemic that led to the closure of schools, data collection was an up hilled task. 


\section{References}

Altweissi, A. \& Maaytah, R. (2022). The effect of using educational drama on developing speaking skill of the sixth graders in the english language. The Universal Academic Research Journal,4(1),10-21.

Anthony, A. (2008). Output strategies for English-language learners: Theory to practice. The ReadingTeacher, 61(6), $472-482$.

Chumbow, B., S. \&Simo-Bobda, A. (1996). The life cycle of post imperial english in Cameroon: In fishman et al, post-imperial English: Status of English after colonialism. NY: Mouton de Gruyter.

Demirbağ,T .(2020). Views of students and teachers about role of homework implementation on students' academic success. The Universal Academic Research Journal,2(2),64-77.

Duman,T. \& Karagöz, S. (2016). An evaluation of Turkish teacher education system compared to other models in different countries. International Journal of Educational Research Review,1(1),1-13.

Ellis, R., \& Collins, L. (2009). Input and second language acquisition: The roles of frequency, form, and function. The Modern Language Journal,93(3), 329-335.

Eposi, J. M. (2009). An investigation into the teaching of writing in secondary schools: The case of government high school (G.H.S) Bokwango. An Unpublished M.A. thesis, University of Buea, Cameroon.

Eyong,E,I., Ugada,C. \& Aminu,A. (2020). Indicators of improved achievement of students' in mathematics. The Universal Academic Research Journal,2(1), 29-37.

Fakeye, D. (2012). Teachers' qualification and subject mastery as predictors of achievement in English language in Ibarapapa division of Oyo State. Global Journal of Human Social Science, 12(3), Version 1.0.

Fonka, H., M. (2014). Decline in Spoken English on Anglophone campuses in the Francophone regions in Cameroon. International Journal of English Language \& Translation Studies, $\quad 2(2), 11-22$.

Fontem, N.A., \& Oyetade, S.O. (2005).Declining Anglophone English language proficiency in Cameroon:What factors should be considered? Globalisation and the African Experience: Implications for Language, Literature and Education. University of Buea, Cameroon.

Gass, S. (1997). Input, interaction, and the second language learner. Mahwah, NJ: Erlbaum.

Hariyani,S. Ahmad,N.J.\&Marsitin,R. (2021). Mathematics teaching practicum for junior high school in a different culture-based situation. The Universal Academic Research Journal,3(2),77-86.

Hart, B., \&Risley, T.R (1995). Meaningful differences in the everyday experience of young American children. Baltimore, MD: Brookes.

Kimberly, B. (2009). Characteristic of effective teachers. Edu books. USA. Retrieved July 6, 2021 from http://www.edubooks.com/author/kaback/ .p.10

Lightbown, P. M. (1992). Getting quality input in the second/foreign language classroom. In C. Kramsch \& S. McConnel-Ginet, (Eds.), Text and Context: Cross-disciplinary and cross- $\quad$ cultural perspectives on language study. Lexington, MA: D.C Heath.

Muza,S.H.(2021). Team teaching approach on academic performance of students in faculty of education. The Universal Academic Research Journal,2(2),58-63.

Nombolo (2005). Instructional approach in sciences: A case study of tom grade 4 classes in the western cape, South Africa. In: Brock-Utne, D’ essai, Zubeida and QorroMaetha (dés). LOITASA research in progress. Dar-essalaam: KAD Associates.

Swain, M. (1988). Manipulating and complementing content teaching to maximize second language learning. TESL Canada Journal, 6(1), $68-83$. 